\title{
Local history as productive nostalgia? Change, continuity and sense of place in rural England
}

\author{
Rebecca Wheeler
}

Land, Environment, Economics and Policy Institute (LEEP), University of Exeter, Lazenby, Prince of Wales Road, Exeter EX4 4PJ, UK, r.wheeler3@exeter.ac.uk

Local history groups are often negatively associated with a tendency to indulge in nostalgic practices that yearn for a romanticised past and propagate resistance to change. Their role in local politics and power networks (particularly in relation to planning and development processes) has also been critiqued as exacerbating issues of social inequality and exclusion. While not contesting the realities of such arguments, this paper adds nuance to such debates by using the notion of 'productive' or 'mobile' nostalgia to explore possibilities for more positive renderings of local history and heritage activities. Empirical evidence from qualitative research in a rural village in Norfolk, England, is drawn on to demonstrate the role of these practices in providing a sense of continuity amid a continuously changing locale through the reassertion of place identities and attachments. Although by no means apolitical, this process need not necessarily be one of preservationism and resistance to change, but can be a mechanism through which residents are able to accept, or even welcome, changes to the social and physical constitution of their village. The paper also critically considers the value of productive nostalgia as a concept through which to explore local history practices and wider heritage movements.

Keywords: Productive nostalgia; local history; heritage; place attachment; rural change

\section{Introduction}

Processes and practices of recalling and recording the past are often associated with a sense of regressive preservationism and resistance to change. This notion is epitomised in the case of local history groups, which are frequently accused of indulging in yearning for a romanticised past at the expense of modernity and development (Jackson, 2008). The political aspects of local history groups are also pertinent in such debates, as the typically elite composition of such 'community' groups' membership has been argued to provide them with disproportionate power over the planning process (Murdoch and Marsden, 1994; Woods, 2005). While not contesting the realities of such arguments, and the issues of social inequalities and exclusionary processes they raise, my aim in this paper is to provide nuance to this debate by suggesting the potential for an alternative, more positive, interpretation of local history practices that recognises their role in facilitating place attachment and acceptance of (rather than resistance to) change within a local context.

This potential is explored through extending recent renderings of nostalgia as a positive and productive phenomenon (Blunt, 2003; Bonnett, 2015; DeSilvey, 2012; Legg, $2004 ; 2005)$ to the case of history and heritage practices at a local level. Evidence from qualitative research in an English village is used to demonstrate the role of these practices in 
providing a sense of continuity and stability amid a continuously changing locale through the reassertion of place identities and attachments. Although by no means apolitical, I show how this process need not necessarily be one of preservationism and resistance to change but can be a mechanism through which residents are able to accept, or even welcome, changes to the social and physical constitution of their village. To some extent, this suggestion follows Lewicka's (2013) contention that an interest in the past is linked to place attachment and can help overcome the spatial disruption experienced by individuals settling in a new place. The paper furthers Lewicka's argument, however, by showing how this interest in the past can also foster a sense of continuity and offer an adaptive strategy for long-term residents who have witnessed change to the place to which they are attached.

I begin by reflecting on the politicised role of heritage practices in place identity processes and conventional depictions of local history as nostalgic, 'backward-looking' and resistant to change. I then introduce the notion of productive nostalgia, before using empirical material to show how this concept offers possibilities for understanding the relationship between local history practices and responses to place-based change in a more positive light. As well as considering the beneficial roles that nostalgia and local history can play in placebased identity processes, the paper concludes with a critical consideration of "productive nostalgia' and its use as a conceptual lens to explore heritage practices both at a local and wider level.

\section{Local history and the politics of heritage}

Investigations into the history of specific local places and the quest to preserve material monuments, manuscripts and other artefacts have longstanding roots (Harvey, 2001; Jackson, 2008). There has, however, been a notable surge in the popularity of local history since the beginning of the nineteenth century and it is now a well-established cultural activity, with over 1200 UK local history societies listed on the Local History Magazine's (2010) website alone ${ }^{1}$. This interest particularly burgeoned during the early-mid twentieth century (Beckett, 2007; Nash, 2005; Sheeran and Sheeran, 1998) due, in part, to a growing societal unease about the eroding effects of industrialisation on places and communities, and an ongoing sense of loss around a pre-industrial world which was (and continues to be) imagined as both more natural and morally sound than the modern world (Ladino, 2010; Matless and Cameron, 2007). The work of renowned local historian W.G Hoskins - such as The Making of the English Landscape (1955), in which Hoskins laments the continued 'uglification' of the countryside and loss of 'true' community due to industrialisation - exemplifies this antimodernist sentiment. Like heritage practices more widely, the increased interest in local history has thus been ascribed as a response to modernity (Hoelscher, 2007), in which the desire for place-rootedness and belonging (Tuan, 1977) is framed as threatened by contemporary patterns of high mobility, 'time-space compression' (Harvey, 1989; Massey, 1994) and 'placelessness' (Relph, 1976).

Set against this background, 'local historical work demonstrates a concern for, and a potential to foster, a contemporary sense of local and regional identity, distinctiveness and consciousness' (Jackson, 2008, p.364; see also Massey, 1995). Matless and Cameron (2007) show how this concern for the local was evident in the activities of Marietta Pallis and friends; a circle of educated women interested in the area of Hickling, Norfolk, in the early twentieth century. Although not originally from the area, these women invested significant time and effort in recording and engaging with local knowledge through the place's people, landscape, ecology and history. Their efforts were centred around celebrating 'the local' (particularly local dialect) in a 'defence of the distinctive and authentic' (Matless and 
Cameron, 2007, p.96), and exemplify how local history began to be used as a way of preserving local identities that were perceived to be 'threatened' by modernity.

The interest in, and use of, the past in constructions of place identity and distinctiveness continues to be demonstrated today in the way that the perceived character of a place and its people is often associated with its historical connotations - for instance, as a working-class industrial area (Mah, 2012), maritime port (Atkinson, 2007), or mining landscape (Wheeler, 2014). These historical representations can provide people with an important link to the 'roots' of a place or (for some) their forbearers, thus contributing to a sense of belonging. However, if place identity is to a large extent based on the past (Massey, 1995) then it follows that changes are likely to be judged partly according to how they 'fit in' with what is customary in that place (Huigen and Meijering, 2005). Similarly, the desire to preserve a place's historical elements can be understood as an attempt to retain or reassert (one version of) its identity. This is problematic because constructing a place's identity according to its past can lead to an essentialisation of place, whereby 'the past' is seen in some sense to embody the real character of the place' and 'a particular relationship between the assumed identity of a place and its history' is presupposed (Massey, 1995, p.183). This essentialisation can contribute to a sense of timelessness, and to a resistance to change, as people seek to conserve the place's character through preserving and reproducing its historical features.

In critiquing such historically-based representations of place, relational accounts have stressed that places should be seen as relational, networked and cosmopolitan topologies that are constantly in the process of becoming (and that cannot, therefore, be depicted by fixed representations of the past). However, this perspective has in turn been challenged as overlooking the tangibility and importance of the local in people's everyday lives, place attachments and sense of belonging (Crouch and Matless, 1996; Tomaney, 2013, 2014). Tomaney (2013) uses references to art, literature and poetry to present a 'defence of parochialism', demonstrating that local attachments can provide a 'progressive mode of dwelling' (Tomaney, 2013, p.5) by prompting a fidelity to place that supports local solidarities and moral commitments - without necessarily denying broader world politics and ethics. Common Ground's Parish Maps project, discussed by Crouch and Matless (1996), offers one such example of how a focus on the local - in this case through the creation of community maps - can be viewed as a 'positive parochialism' that 'acknowledge[s] the multiplicity of place' but 'resist[s] the temptation to track down an essence' (Crouch and Matless, 1996, p.252).

To some extent, this paper provides some support to a defence of parochialism, as I demonstrate how local history practices can perform a positive function for individuals and communities in the creation of place attachment and a sense of belonging. However, as Tomaney (2014, p.5) suggests, 'the notion of a binary opposition of cosmopolitan outlook versus local attachment is unhelpful'. Hence, it is the tension between the productive and exclusionary elements of place-based localism that I explore here through a focus on local history and productive nostalgia. Accordingly, despite the potential merits of localism, the problematics suggested by an essentialist position remain germane in the traditional characterisation of local history activities as backward-looking and resistive. While local history societies may have the potential to cultivate cultural identity and contribute to social cohesion (Beckett, 2011; Jackson, 2008), they are also often associated with a tendency to yearn for a lost past and resist change, with implications for the acceptance of planning proposals or other place-based changes. Such critiques are linked to wider notions of the past as being restrictive over the present. As Ashworth and Graham (2005, p.10) articulate:

The past can be a burden in the sense that it often involves a dispiriting and negative rejection of the present. Thus the past can constrain the present, one of the persistent themes of the heritage 
debate being the role of the degenerative representations of nostalgic pastiche, and their intimations of a bucolic and somehow better past that so often characterise the commercial heritage industry with supposed deleterious results of society and economy.

This desire to engage with the past and preserve its artefacts gives rise to a number of issues relating to power, identity and exclusion that have been discussed at length within heritage studies literature (e.g. Harrison, 2004; Lowenthal, 1998; Said, 2000). These debates will not be repeated here but, importantly, they have exposed heritage as a highly situated and contested term, highlighting how what counts as heritage is open to multiple interpretations that shift over both space and time (Harvey, 2001). Despite this fluid and pluri-semiotic nature of heritage, related practices are dominated by what Waterton and Smith (2010) term the Western Authorised Heritage Discourse (AHD), which tends to present heritage as unchanged and unchangeable, validating what is or is not 'heritage' and obscuring alternative (less elite) versions of the past (though note that the AHD is increasingly being challenged by non-elite groups who are 'reclaiming' their cultural heritage - for example in postcolonial (De Jong and Rowlands, 2007) and working-class (Smith, Shackel and Campbell, 2012) contexts).

Politicised notions of heritage also apply at the local level and, since 'community' groups like local history societies tend to be socially biased in terms of being dominated by middle-class residents (Sturzaker, 2010; Tewdwr-Jones, 1998; Yarwood, 2002), these groups can hold disproportionate power within the community and are inescapably embroiled in local politics. In an exploration of writings in a county history society's journal, The Devon Historian, Jackson (2008, p.370) points out that local historians have developed 'a greater statutory profile in the planning consultation process' and that planning officers within the society's membership 'have encouraged the forging of the bridge between the practice of preservation and research in local history'. The implied influence of local history societies over the planning process is clear, with their preservationist interests at times conflicting with development agendas. In some cases, social heritage preservation can also be used as a pretext to obscure and protect more individual concerns in efforts to block unwelcome developments (Huigen and Meijering, 2005) - a process arguably exacerbated in a rural context where middle-class residents have a particular fiscal and emotional investment in the idea of a 'rural idyll' (Duncan and Duncan, 2004; Murdoch and Marsden, 1994). As my own research found, local history groups can also be fraught with internal politics that exacerbate social divisions within communities and highlight the contested nature of heritage 'knowledge'.

There is no doubt that these political issues associated with heritage practices are real and have tangible effects on the management of our built and natural environment. This does not, however, mean that an interest in the past should unquestionably be correlated with a negative attitude towards modernity and change. If heritage practices and artefacts are viewed, as Lowenthal (1985) argues, as a way of fulfilling a need to connect the present to the past in a continuous notion of progressive, evolutionary social development, then attending to the past simply 'offers a sequence, allowing us to locate our lives in linear narratives that connect past, present and future' (Ashworth and Graham, 2005, p.9); a notion that does not necessarily preclude a sense of termination or an acceptance of change. This relational, processual approach to place temporality is recognised and accommodated within notions of engagements with the past not as regressive but as enrolling a productive nostalgia; a concept to which I now turn. 


\section{Productive nostalgias}

Negative appraisals of history and heritage practices as constricting the present generally accuse them of being bound up in romantic nostalgia - a concept which has traditionally been derided as a regressive, irrational and inaccurate form of remembering (though no form of memory can be described as authentic, as all are bound by the cultural and political contexts in which they are recalled (Cubitt, 2007; Said, 2000)). Furthermore, as part of the AHD, there is no escaping the fact that nostalgic images can work to mask reprehensible processes of discrimination and exclusion that permeated the past (Watson and Wells, 2005). Recently, however, a blanket derision of nostalgia has been challenged and more positive outcomes of nostalgic imaginings and practices explored. These more positive interpretations have been variously framed as 'productive' (Blunt, 2003), 'mobile' (Bonnett and Alexander, 2013) or 'counter' (Ladino 2004) nostalgias (see also Mah (2012) on 'living memory' and Legg (2005) on 'counter-memory').

Focusing on the case of McCluskieganj, an Anglo-Indian settlement established in 1933, Blunt (2003) returns to nostalgia's linguistic origins as referring to a yearning for home - a kind of temporal homesickness - to explore how nostalgia does not only exist in narrative and imagination but can be embodied and enacted in social practice, thereby facilitating a productive process. The founders and settlers of McCluskieganj sought to create a 'homeland' where Anglo-Indians who lacked a sense of belonging within either the British or Indian communities could celebrate their Anglo-Indian identity and establish their own sense of home. At times ridiculed by both the British and Indians for dreaming of (an Imperialist vision of) Britain as home and indulging in Raj nostalgia at a time of colonial departure, Blunt describes how it was the nostalgic desire for home that drove Anglo-Indians to actively produce a new settlement - a political and liberatory endeavour that was oriented towards creating a positive sense of belonging in the present and the future. Nostalgia thus performed a positive and productive function.

Similarly, Ladino (2004, p. 89) reveals a 'counter-nostalgia' within American Indian storytelling that suggests nostalgia 'can be a mechanism for social change, a model for ethical relationships, and a useful narrative for social and environmental justice'. Elsewhere, Mah's (2012) notion of 'living memory' implies that, since memories are always embedded within present contexts and social and economic change, we cannot distinguish between nostalgia as dwelling in the past and as looking to the future. Legg's (2005) exploration of 'sites of counter-memory' in colonial Delhi also demonstrates how nostalgia and a refusal to forget can be enacted in a political performance that creates spaces (material or symbolic) for resistance to more historical narratives.

Bonnett and Alexander (2013) welcome such positive interpretations of nostalgia but, building on the arguments developed by Bonnett (2010), problematize attempts to separate it out into its restrictive and liberatory forms - i.e. a 'restorative' nostalgia that seeks to reconstruct and preserve the past and a 'reflective' nostalgia that is ironic and progressive (Boym, 2001). Drawing on interviews with ex-residents of Tyneside still living nearby, the authors demonstrate how sentiments can seamlessly shift from a sense of desire for the streets, shops and 'community' of the past to a futuristic ambition for a rejuvenated modern city. The term 'mobile nostalgia' is employed to suggest that 'we should see nostalgia, not as something fixed or passive, but as a dynamic process that develops in relationship to, and shapes, human activity' (Bonnett and Alexander, 2013, p.394). Such an approach elides distinctions between 'forward' and 'backward' looking nostalgias, instead reflecting the complexity and interconnectedness of emotional relationships with the past (Bonnett, 2010, 2015). 
Collectively, the studies discussed above reveal the potential for nostalgic memory to be a fluid, plural and active social force through which narratives of loss can be politically mobilised to shape present and future social behaviour. These framings of nostalgia have helped to counter some of the derision conventionally associated with 'romantic' engagements with the past, and this has implications for re-thinking the tensions between heritage practices and change. Such interpretations of nostalgia resonate with relational accounts that emphasise the processual nature of place as never complete but always in a continuous state of becoming (Massey, 1994; Pred, 1984). From this perspective, heritage can be seen as enabling a temporal narrative where selected materials from an imagined past provide resources for an imagined future (Ashworth and Graham, 2005).

Despite increasing recognition of the relational nature of heritage and its role in processes of place identity, belonging and social cohesion (Ashworth and Graham, 2005; Jackson, 2008), there has been little attempt to connect this with the notion of productive nostalgia in the context of local history-oriented activities. Of relevance here, however, is Lewicka's (2013) work on the role of local (and family) history practices in the creation of place attachments among new residents. Contextualised primarily within the environmental psychology literature on place identity and attachment, Lewicka's work does not utilise the terminology of 'productive' or 'mobile' nostalgias, but she does focus on how nostalgia can act as a positive force by restoring a sense of self-continuity for place-mobile residents. Her research on place attachments in Poland and Ukraine (Lewicka, 2011) revealed newer residents to have a greater interest in local history than longer-term residents. For these people, learning about the new place in which they lived (and/or their own family histories) provided a way of situating themselves within a continuous narrative linking past and present, thereby asserting a sense of belonging and developing an 'active attachment' to the place.

Lewicka argues that developing knowledge about local history enables the temporal dimension of place attachment to be fulfilled for new residents through the development of declarative ('knowing that') memory. This role is usually achieved for long-term residents with a 'traditional attachment' to place through procedural ('knowing how') memory, which is developed over time through the performance of everyday habits and routines - or 'place ballets' (Seamon, 1980). From this perspective, the nostalgia implicated in an interest in local or family history can be seen as an enabler of place attachment. Thus, 'nostalgia is adaptive: it helps to put together broken parts, builds a bridge between past and present, increases selfesteem and life satisfaction, and reinforces social ties' (Lewicka, 2013, p.53).

This paper builds on Lewicka's argument by exploring how the 'bridging' capabilities of nostalgic local history practices in providing a sense of continuity between past, present and future can serve as a mechanism for coping with place-based change. The adaptive capacity of nostalgia emerges as relevant not just for new residents whose place attachments have been disrupted by mobility (as in Lewicka's work), but also for place-attached residents who are experiencing changes (either material or social) to the place itself.

Though I aim to draw out the positive elements of local history practices and productive nostalgia for processes of place attachment and adjustments to change, I stress that this should not be interpreted as an uncritical advocacy of all such activities. With regard to local history groups in particular, the potential capacity of local history to provide a sense of continuity during times of change is by no means always realised and the resistive tendencies of local history discussed earlier remain salient. Neither do the potential benefits subsume or resolve the issues involved in warm and fuzzy representations of 'community' heritages (Waterton and Smith, 2010) and their role in the construction of seemingly stable, bounded places (Harvey, 2014). This paper is not, therefore, a challenge to the reality or importance of such political issues. Rather, it draws out the nuances involved in local history as both social practice and individual pursuit by suggesting that its preservationist qualities can be 
accompanied and tempered by the presence of a continuity-providing potential that mediates responses to change and offers a productive function (at least at some level and to some people).

\section{Research context and methodology}

The interplay between local history practices, nostalgia and responses to change is discussed below through the case of Martham, a relatively large village (population 3,569 in 2011) situated approximately three miles from the East Norfolk coast on the edge of the Norfolk Broads; a $300 \mathrm{~km}^{2}$ network of shallow waterways and lakes popular for boating and other recreation. The Broads, along with a flat, scenic landscape, traditional windmills and picturesque villages, make Norfolk a popular destination for tourists and urban-rural migrants who are attracted to the countryside by (often idealised, nostalgia-imbued) notions of landscape, nature and community (Bunce, 2003; Matless, 1998). Martham has thus grown steadily since World War II and is inevitably prone to the social issues associated with counter-urbanisation, such as debates over the increase in second-homes and gentrification (Phillips, 1993, 2002) and frictions between 'local' and 'incomer' groups (Bell, 1994; Day, 1998; Woods, 2011).

The findings presented here emerged from a wider research project that explored experiences of place and change in three English villages through a mixture of walking and indoor interviews with residents. The research in Martham was conducted during September 2013 and included twenty-seven interviews; eight of which were conducted as walking interviews. The selection of a mobile or sedentary interview was determined by participant preference (influenced by factors such as personal mobility and weather conditions), though walking interviews provided the added benefits of providing visual references to participants' narratives and offering the researcher insights into the affective, emotional and embodied aspects of relationships with place (Anderson, 2004).

Interviewees were initially recruited through the use of 'gatekeepers' (Cloke et al., 2004) such as the parish council and - significantly for this paper - the local history group, followed by the subsequent use of stratified snowballing techniques (de Wit, 2012). Residents representing a range of ages and residence-lengths were interviewed, although there was a slight bias towards older, longer-residing people. This bias partly reflects the older than average demographic of the village (and the groups used as gatekeepers), but it is also likely to result from the self-selecting nature of the sample, as older residents may have more time for (and interest in) the research. Note that, in the interests of confidentiality, all names used in this paper are pseudonyms.

Participants were asked to talk about their experiences of living in Martham, including the aspects that they most valued and how they felt the village had or had not changed over the time they had known it. Although the interviews covered a range of placebased themes and issues, local history repeatedly emerged as a topic of interest within interviewee accounts, prompting further discussion about the reasons behind this interest and the various related practices that took place within the village. Narratives included both positive and negative portrayals of the Martham Local History Group (MLHG) and its activities - an organised group established in 2010 which currently has over 50 members, an extensive website, and regular meetings. Other, more individual and less 'formalised' interactions with the physical and social history of Martham, such as collecting old photographs and swapping stories with friends, also emerged as important ways of establishing and maintaining connections with, and creating particular knowledges about, the place for long-term and newer residents alike. As I explore below, closer analysis of these 
various discussions reveals traces of both a preservationist tendency and what might be considered a more productive nostalgia within individual and social engagements with Martham's past.

I begin by discussing how nostalgic narratives and images of Martham are entwined with representations of rural place, and considering the potential implications of this for how change in the village is perceived. Having acknowledged and outlined the presence of resistive elements within local history practices, I then explore the more productive roles that these play within the village; firstly in establishing and demonstrating personal connections to the place, and secondly in reinvigorating and performing notions of 'community'.

\section{Research findings}

\section{Rural place, the past and attitudes to change}

'I moved to Norfolk because I like the quiet pace of life... Martham's like a time capsule really things as they used to be' (Gerald, resident for 2 years).

'Martham retains much of the charm of a traditional English village, epitomised by its village greens and ponds' (Martham Parish Council, 2010, [online]).

The above quotes are indicative of how individual and 'community' constructions of Martham's identity often enrol ideas about a 'traditional' English village where residents can enjoy a slow and simple rural living away from the hustle and bustle of modern - or urban life. Such notions are reflective of romanticised representations that depict the countryside as an idyllic, traditional place that has escaped the typical pitfalls and time-pressures of globalisation and modernity (Bunce, 2003; Short, 1991; Woods, 2011). This forms part of the attraction of rural life and construction of rural identity for many people, but such idyllic timelessness can disguise the processes of change and transformation that places have constantly undergone and promote a desire to preserve them in a form of historical stasis (Massey, 2006; Pred, 1984). Arguably, these processes may be reinforced by local heritage practices that reinvigorate nostalgic images and mourn the changes that have occurred. The following excerpt from a section of the MLHG website containing historic and contemporary aerial photographs typifies such sentiment:

\footnotetext{
Early photos have become historical records. Compare them with modern aerial photographs and the massive, sometimes devastating change is starkly revealed. What a lovely secluded country village was Hemsby [a neighbouring village] in the 1930s. How unlovely it looks from the air right now.
}

(Martham Local History Group, 2012, [online])

Other narratives were also imbued with a seemingly restorative, backward-looking nostalgia that depicted the past as preferable to the present. For instance, many interviewees expressed a sense of loss over shops that had changed over the years, or bemoaned the increase in housing developments and in-fills within the village (though such objections were usually presented as relating to the inability of existing infrastructure and services to cope with the pressures of development). I was also shown numerous photographs and other memorabilia from Martham's 'bygone days' by both members and non-members of MLHG who clearly treasured the personal and social memories these represent (and reproduce).

Chiming with the academic debates about local history and heritage discussed earlier, some interviewees explicitly associated MLHG with efforts to resist change. One lifelong 
resident, Mike, for instance, talked about his concern that attempts to record and remember Martham's past must be balanced with providing for current needs:

Housing-wise, housing is required. But there was a bit of an uproar [about one development] and again, opposite this estate they've developed a piece and there was an old house there and the history group were fighting to try and save it. And to be honest, building-wise, the house was nothing. It didn't look anything. So it was all well and good but [sentence unfinished].

Despite such negative perceptions, narratives from the wider interviews suggest alternative perspectives and interpretations of the motivations behind local history practices co-exist alongside resistive tendencies. Interviews with MLHG members revealed that their concern to record and preserve the past did not necessarily preclude an acknowledgement that change is an inevitable and necessary part of contemporary rural life. For instance, one lifelong resident and member of MLHG, Mark, who placed significant value on local history, recognised the potential for an emphasis on heritage to result in a sense of static-ness but spoke about his own openness to change:

[One person I know] has tried quite hard to stop things from being changed. You know, he has been [objecting to things], which is, I know why he did because you need to keep your heritage. And I agree with that. But you need to change as well, you can't live in the past. You can't. So I don't mind it changing, because it has to.

Nostalgic sentiments and preservationist tendencies enrolled in local history practices are therefore balanced (among both members and non-members of MLHG) by an interest in generating and maintaining a 'living' community that retains a link to its past but is firmly placed in the present and provisioned by 'modern' services including schools, public transport and health facilities. As I explore further in the section on 'performing community', several MLHG members who reminisced over the 'community' spirit of Martham's past were also active in seeking to revive and sustain this through their involvement in other groups and support services (e.g. the village library, community café, and youth club). Apparently 'backward-looking', resistive sentiments inherent in local history can thus be productive in themselves by promoting an enthusiasm for locally-focused stewardship and action.

This link to the past also provides an element of continuity that helps to accommodate place-change. Although not all residents displayed an active interest in the place's history, when asked they all felt some sort of recording of, and engagement with, the past was important. Participants generally found it difficult to articulate reasons for this importance, as it was not something they had previously considered. After deliberation, though, the common response was that the importance of recording history relates to a desire to understand the place's origins and highlight its continuity in spite of change. As Mark explained (in response to the question 'why do you think it's important to keep those memories recorded?'):

\footnotetext{
Hmm, that is a good question. I don't know how to answer that. Because it means a lot to me and, well I know the younger people like to see it as well, they like to know what we got up to and how we used to do things really. That's important. Because I know I'm interested in what little I know of what the older people used to do before me. And that just gives you a link I suppose to the past and to the village and to what used to be.
}

Mark's initial difficulty in answering the question indicates that his interest and participation in local history practices is undertaken without close reflection. Yet, it is clearly an important aspect of his relationship with Martham and is linked both to his attachment to the place and his belief that village knowledge should be passed down to younger generations in order to maintain the continuity of community. Mark's earlier recognition that 'you need change' suggests ensuring the survival of stories and memories about Martham facilitates this 
continuity through recognising and accommodating, rather than deploring, change. This accommodation of change is important because, as DeSilvey, Naylor and Sackett (2011, p.10) suggest, 'history that calls attention to process rather than permanence may...help us to be more prepared for future change'. Yet, attending to process and transformation within local history narratives is not a straightforward process and is often entangled and juxtaposed with what might be perceived as a more resistive disposition.

The plural and fluid nature of perceptions of heritage and change was particularly demonstrated in the account of Mary (resident for 47 years), an active member of MLHG who was passionate about researching and recording all aspects of Martham's history. During our interview, Mary guided me around the village and detailed the history of many of its buildings and features, in particular pointing out sites that MLHG had sought to protect from redevelopment. Her account suggested that her local-history related activities were partly driven by a general interest in wider history, but were also bound up with a concern to maintain traditional, 'rural' characteristics that she saw as central to Martham's identity. For Mary, the village green serves as a particularly tangible feature of Martham's heritage that she is keen to conserve close to its 'authentic' state, but which she considers to have been inappropriately altered by 'incomers' to the village:

\footnotetext{
You see, people coming into the village have different ideas about things and have gradually changed it. They've put a lot of effort into tidying it up and wanted to put more colour into it. So they've planted various trees and put in these huge wooden boxes for flowers. I mean these [flower boxes] are so suburban it's untrue. They're out of keeping with what the common should be about. I mean the commons wouldn't have had any of that.
}

Nevertheless, while Mary was keen to conserve certain aspects of Martham's past, she was not resistant to all changes, particularly if she perceived that change to support community life. For instance, she was especially supportive of the recent construction of a new secondary school. She was also pragmatic about 'modern' additions to the village and indicated that her evaluation of features in Martham's landscape was not solely predicated on historical merit. This acceptance of 'modern' objects emerged during a conversation about local windfarms:

I quite like them. I think these ones (pointing to the local turbines) are quite artistic. I don't like the ones with just two blades though, they're just ugly. But generally I don't mind modern equipment in the landscape at all, so long as they are well-designed. Even electricity pylons.

Thus, while in some respects Mary's passion for local history leads to an essentialisation of Martham's identity and a desire to fix this through the conservation of heritage features, her account reveals the complexity and context-dependency of responses to physical change. For Mary, it is the retention of some material symbols of heritage - rather than a complete nostalgic reproduction of a lost past - that is important in maintaining Martham's identity. Her efforts to maintain elements of Martham's identity are also linked to the construction and assertion of her own identity as someone who belongs in the village (despite not having been born or raised there); an identity which is, in part, relationally constructed against her perception of people who have 'come into the village' with 'different ideas about things' and who, by implication, are 'different', less 'rural', and less knowledgeable about Martham than herself. The assertion of place identity through local history is, therefore, a contested process that in some circumstances can threaten, as well as promote, social cohesion within communities. 


\section{Local history, place attachment and contested ways of 'knowing'}

Conversations with both members and non-members of MLHG revealed interesting notions about local history as a (sometimes contested) way of 'knowing' the place and identifying with past inhabitants. For instance, one returnee to Martham, Adam, who was raised in the area but lived elsewhere for several years, used his earlier connection to Martham to explain his lack of interest in local history:

RW: 'Do you take much of an interest in the history of the area?'

Adam: 'I don't, because I've always been here. I think more people who've come into the village are more interested.'

RW: 'Why do you think that is?'

Adam: 'Well I know the place. I can trace it right back to, phrr, 1941 when I was fourteen.'

Adam interpreted local history practices as a way of establishing a knowledge of, and thus connection with, the area. Since Adam already 'knows the place', he does not feel a need to expand this knowledge further by participating in such practices. His belief that people who have moved into the village are more interested, while not universally true, was reflected in the membership composition of the local history group and supported by the accounts of two newer residents:

I think when people come here they should find out the history of the place. I tried to find out, I'm interested.

(Bruce, resident for 6 years)

Um, I don't know [what makes people interested in local history]. I don't think it's because necessarily they've been here a long time. I think if you were to look at people who are part of the historical society, quite a few of them are newcomers and I think they come with that energy and interest that they're investing in the new place they live. And I suppose that would be my view...I like the stories.

(Anita, resident for 10 years).

The observation that newcomers are particularly interested in Martham's history supports, in part, Lewicka's (2013) argument that local history offers new residents a way of developing place attachments through understanding more about the place and establishing a connection with its past. However, it also became clear that it was not only newcomers who took an active interest in local history. Lifelong residents often displayed a keen interest in Martham's past (particularly its social history) and expressed a personal connection to the people and place being remembered. Participants recalled stories that had been told to them by their parents or grandparents about the everyday goings-on in the village, how things were done 'in the old days', and particular 'characters' who had lived there. These characters were proudly depicted as archetypal individuals who exemplified the values of 'country folk' and embodied the place's identity:

Oh yeah, the old characters. When I was young we had no end of old characters, some of them were quite scary really. I don't think they meant to be, but that's just how they were. They were country folk, and they used to have a right go at us lads sometimes. But yeah, we've nearly lost all of them now, there's not too many left now.

(Gareth, resident for 60 years) 
There is clearly an emotional attachment to the social memories contained in residents' oral histories and historical materials, and the recording of these is seen as a way of ensuring their continued survival. As Duncan (a lifelong resident) explained:

I've always been interested in village life. And that's why for fifteen, twenty years I've collected old stuff on the village. I must have over eight-hundred photographs, I've got books, and old mementoes...I just think that if people don't keep collecting stuff like that then it's all going to be forgotten - what went on, years ago. Because a lot of people have all these lovely old pictures, old photographs, and when they die they just throw them away.

As these accounts convey, many of the memories and images residents shared with me were infused with nostalgia and romanticism (and recognised as such), but their re-imagination serves to reiterate links with past inhabitants and propagate interest in recent social history. The circulation of photographs, stories and historical materials within the community provides people with a sense of inclusion and belonging, thereby incorporating them into the 'story' of Martham. Physical and virtual social spaces and practices, such as history group meetings and a Facebook page dedicated to 'Memories of Martham', also offer forums where residents can share and accumulate their knowledge of the village's past. Researching and remembering local history is seen by lifelong and newer residents alike as 'finding out about our forbearers and where we come from' (Carl, resident for 10 years).

Nostalgic local history practices thus emerge as a mechanism through which inhabitants establish, deepen and perform their knowledge of, and sense of belonging in, Martham. However, the nature of this local 'knowledge' can be contested and divisive. For some lifelong residents, the accuracy of social history is regarded as vital and this concern can cause tensions and provoke resentment against newer residents, who tell alternative versions but are deemed to lack the relevant knowledge and experience. One example of this was an anecdote relayed to me by Duncan:

\footnotetext{
Well you get, the history group, people come there what aren't really Martham people but they're making out they know all the stuff on Martham. I went in the butcher's a few weeks ago and there was a woman who was running on, she was saying, 'oh yes I've been doing all the research on Martham ponds and there's only ever been four ponds'. I said,' whatever are you on about? You're a non-local squit, I can name seven now'. 'You cannot'. I said 'you want a bet love?'...And that annoys me, you know, they make out they know everything but they don't.
}

Knowledge of Martham's past was used in Duncan's account both to reiterate his own status as someone who 'knows', and therefore belongs in, the village and to de-legitimise the position of someone he saw as an outsider. Similarly, another lifelong resident, Ray, expressed irritation at one particular 'incomer' making certain claims about the village's history, and used his status as someone 'who's lived here all my life' to dispute these, positioning his own knowledge as more accurate and authentic:

This one guy, he's moved here and thinks he knows the lot, but he's been here 5 minutes. I'm the only one on the history group who's lived here all my life, and when I start telling them something he starts butting in. It's not right. I catch him out.

Thus local history practices are not always inclusive and harmonious, as multiple and competing versions of the past can accentuate dividing lines between social groups and form a source of conflict as well as cohesion. 


\title{
Performing 'community' through nostalgia: the case of 'Martham Stories'
}

In addition to contributing to individual constructions of place attachment, nostalgically reproducing Martham's past also emerged as a key mechanism through which social memories were perpetuated, and through which people practiced 'community' and local cultural identity (as also reported by Beckett, 2011; Jackson, 2008; Mackenzie, 2006; Nash, 2005). This 'community' building potential of local history practices is particularly drawn on by MLHG, as demonstrated by the following statement on their website:

\begin{abstract}
Our activities are intended to draw people together by encouraging them to co-operate in learning about and recording the history of their own village and locality. People have shared memories, knowledge and skills across the generations, thus enhancing a sense of belonging in the present whilst developing a connection with the past. Our activities have supported the education of young people and have valued the experience of the older generation.
\end{abstract}

(Martham Local History Group, 2015, [online])

Traditional practices, such as the annual village carnival (that the MLHG takes an active role in organising) provide a means of integrating current residents into the 'story' of Martham through linking past, present and future performances of community. A notable communitycentred local history activity in which MLHG members were involved, and which was mentioned to me on several occasions by a variety of residents, was the creation of a DVD titled Martham Stories. Martham Stories consists of short films about the village's history and was produced with the support of MLHG and Flegg High School ${ }^{2}$. Described as aiming 'to collect reminiscences on a wide range of topics including school life, the railway, village carnivals and the impact of the war years' (Media Projects East, 2013, [online]), the project featured local historians speaking about their knowledge of Martham's history and older residents telling stories about village life within their living memory. The films were compiled into a DVD, which was 'premiered' at the high school in May 2013 (four months before my visit to Martham). The stories that were told included 'A Farming Family', 'Carnivals', 'Fire and Flood', and 'The Village Butcher'. These highlighted positive aspects of Martham's identity (and were undoubtedly chosen for this reason) by emphasising rural practices (e.g. farming), traditional events (e.g. carnivals), community spirit in times of crisis (e.g. during severe flooding in 1938), and 'village' features (e.g. the butcher's), throughout recent history. The Martham Stories project, therefore, emphasises and reproduces aspects of Martham's identity and celebrates its heritage through the telling and recording of social memories.

Judging by the responses of interviewees, the DVD was a popular and well-received project. People particularly commented on their enjoyment of learning about life during the war, childhood pranks, and general village life in the past. There was also a sense that the project had engendered a sense of community by involving local schoolchildren and longstanding residents and that it had produced something of value to the community, both now and in the future. Much of this value was related to the DVD's ability to capture stories of the past for future generations to enjoy, before they are 'lost':

There's so much local history, so many stories yet to be told. It's nice for older people to pass on
their stories. It's so interesting. I think it would be lovely to have all their stories written down, so
everyone can enjoy them. Like when the DVD came out and the woman told about when she was
machine-gunned in the war, I didn't even know about that. You know, you think of these things,
and they're all gone - since those people have died, those stories have gone with them.

(Angela, lifelong resident)

Undeniably nostalgic in tone, Martham Stories included narratives of hardship and poverty (particularly relating to the war), as well as romantic portrayals of a traditional and close-knit 
community. The shifting, mobile nature of nostalgic recollections that Bonnett and Alexander (2013) discuss is thus evident in the way that the DVD's narratives and images are not purely restorative in sentiment. The juxtaposition of both positive and negative elements of the past serves to emphasise elements of change that have been welcomed, alongside those that are mourned. For instance, one resident talked about how she used to hate the manual labour involved in harvesting sugar beet before the mechanisation of farm machinery, and this sentiment was echoed in similar stories (both in the films and my interviews), which highlighted the 'hard' manual work that youngsters were expected to carry out in industries such as coal and farming. Such accounts relationally positioned (this aspect of) quality of life in the present as preferable to the past; an improvement made possible by modernisation and changes to local and wider socio-economic opportunities and conditions. The DVD's production and celebration in present day Martham has also been a conscious attempt to promote social cohesion and enact a sense of 'community' through retaining social history and connecting residents with the village's past.

In this respect, the nostalgia invoked in local history practices such as the Martham Stories project can be described as productive but, as highlighted in the discussions earlier, this remains a problematic and contested process. Transposing oral histories into material artefacts such as a DVD necessarily entails a certain fixing of these histories through the selection and editing process. One lifelong resident, Ray, for instance, disagreed with the choices that were made about what to include in the DVD and felt that stories told first-hand by older lifelong residents should have taken priority over 'less knowledgeable', 'nonMartham' people:

\begin{abstract}
I told that story on there, but half of what we done on that they never put on there. And that was a pity really because me and [my friend], we told them all about how my grandfather was a [local craftsman] and how he used to do things, but they never did put it on there. But then there was another two people on there who I don't think should have been to be honest. Half of what they were going on about was nothing to do with Martham. It's a pity really because we were the people who still lived in the village, a lot of the other ones had, they'd come here if you know what I mean, but we were born here.
\end{abstract}

This reiterates the earlier point about divisions between lifelong and newer residents, but it also highlights the way that the contested nature of knowledge about local history can be obscured by material artefacts that present events as undisputed. One particular feature on the DVD, which claimed that the marshes of nearby nature reserve Heigham Holmes were used to land and re-fuel spy planes during WWII, emerged as particularly controversial, even among lifelong residents. For instance, Mark could not believe that this could have been kept a secret in such a small community and, therefore, objected to time being devoted to it on the DVD:

The ending, that annoyed me a bit. Because I don't believe that's true, about the airfield. Because if you live in a village like Martham, if that had been going on there was no way they would have kept that secret. Because from where the church is, you can see all those marshes, you can see everything that goes on there, and the guy said 'well of course they used to come in there and refuel'. Ok, so how did they get the fuel over there? That's absolutely crazy that is. And instead of doing that they could have put such a lot more into [the DVD], because there was quite a long section which I didn't think was true.

Yet, another lifelong resident, Ray, asserted his first-hand knowledge about the rumoured airfield and relayed this with a notable sense of pride:

They phoned me up from the headquarters about it, because no one knew nothing about it, and I said my father worked over there all the war. And the guy said 'oh, what do you know about it?' And I said, 'it's got nothing to do with you, I ain't telling you what I know'... There was a grass 
landing strip over there and he said, 'do you know where it was exactly?' I said yeah, I know exactly which marsh it was, my father used to tell me, but I said I'm not telling them, because I ain't allowed over there.

Ray's refusal to share his knowledge about the airfield with someone outside the community is linked to an issue around public access to Heigham Holmes, which, for conservation reasons, is now only open to the public on one day each year. Ray (along with several other residents) feels a certain ownership over this land and is, therefore, perturbed at being prohibited from going there. His wish to keep his knowledge to himself is a response to this, and can be described as an attempt to retain and reassert a sense of local control and ownership over the site. Such actions suggest how local history might be used as a mechanism to resist and subvert authority, and to reinforce notions of community 'rights' over a place.

\section{Re-thinking local history and place attachment through productive nostalgia}

I have argued that although producing materials about local history involves indulging in nostalgia through representing images of the past, this is not a simply a backward-looking pastime, as it fulfils emotive desires to establish and perpetuate personal connections with places in the present. Performing local history and heritage can be seen as a relational and productive process, connecting individuals to wider social memories and practices and serving as a means of sustaining place identities through times of change for both long-term and newer residents. Local history does not, therefore, necessarily involve preserving the past but can allow room for change and flux to be welcomed as inevitable in the ongoing becoming of place. Furthermore, as Mackenzie $(2004,2006)$ has argued in reference to crofting communities in Scotland, identity and belonging may be enacted through historical references and the continuation of traditional practices, but this is not a rigid or essentialist process. Rather, practices emerge as contingent and dynamic, shaping and re-shaping individual and collective articulations of rural community and belonging according to contemporary contexts and actions.

The nostalgia bound up in local history practices provides people with an affective connection to the place's past, which, while at times mournful, can also be productive by offering a sense of personal and social continuity and by facilitating an ongoing enactment of 'community' within the village. The productive nature of nostalgia can, therefore, be linked to Lowenthal's identification of continuity as a key attribute of the past, for;

\footnotetext{
Celebrating continuity, as distinct from antiquity, is profoundly anti-escapist. The accretive past is appreciated less for its own sake than because it has led to the present...continuity implies a living past bound up with the present, not one exotically different or obsolete
}

(Lowenthal, 1985, p.61)

As I have shown, this is by no means an unproblematic process and the assertion of knowledge pertaining to local history is infused with contestation and inflected by the power dynamics inherent in community (and wider) politics. It is also important to remember that nostalgic images can work to disguise the social divisions of the past and reflect the lives and memories of only certain, privileged individuals or social groups (Watson and Wells, 2005). When considering nostalgia as productive we must, therefore, be conscious of the question; for whom is it productive? The revival of historic images and narratives may enable some local residents to reaffirm their version of place identity, continuity and attachment, but these actions might simultaneously exclude others from the community if they result in (for instance) the blocking of new affordable homes amid the historically-based gentrification of 
an area. The risk is that in championing the benefits of nostalgia we facilitate the disguising or condoning of exclusionary resistive actions. In light of this, the need to recognise the complexity of, and tensions between, the potential implications of nostalgic work (and, as Bonnett $(2010 ; 2015)$ advocates, to avoid presenting a binary of restorative or reflective nostalgia) becomes vital.

Despite these issues, I contend that productive nostalgia remains a useful concept for social and cultural geographers, as it offers a way of exploring the useful social and personal functions that nostalgic practices play. For instance, acknowledging a more positive interpretation of the role of local history in influencing responses to change may provide space to explore and engage with such practices in a manner that fosters nostalgia's productive elements and more sensitively addresses contestation. On a broader scale, recognition is growing in multiple contexts about the value of using place-based histories in heritage projects that seek to look forward in celebrating multiple cultural identities and promoting social equity. For instance, the Australian Indigenous Heritage Programme (Australian Government, 2014) promotes Aboriginal and Torres Strait Islander identities through funding cultural heritage projects. Elsewhere, the Tourism RESET (Race, Ethnicity and Social Equity in Tourism) (2016) initiative explores efforts to include the slave experience within plantation heritage; and analyses white-centric representations and counternarratives within Civil Rights Movement heritage. The concept of productive nostalgia provides a useful way of considering how everyday local heritage practices - both individual and community-based - might spark and interact with these broader movements and politics.

\section{Conclusion}

Exploring local history practices in Martham through the lens of productive nostalgia has provided a way of looking at the role of the past within processes of place attachment and identity that goes beyond a simplistic insinuation of essentialism and critically acknowledges the intertwining functions (both good and bad) of memory, history, emotion and a concern for 'the local'. The case study also contributes to the recent re-thinking of nostalgia by demonstrating how nostalgia can perform a productive function in the everyday lives of nonmarginalised groups, as well as in the more overtly subversive or 'progressive' projects undertaken by minority groups (which have more commonly been attended to elsewhere, e.g. Ladino 2004, Legg 2005, Tabar 2007). Furthermore, the place-based activities of Martham residents have underscored the need to avoid simplistic distinctions between a 'positive', forwards-looking nostalgia and a 'negative', backwards-looking nostalgia, as historical narratives were used within imaginings of the place's past, present and future. The enjoyment and local attachment derived from 'indulging' in nostalgia (for both individuals and the community) can prove it to be a productive force, but this does not negate the problematics of inter-community tensions inherent in local history practices and its potential role in more resistive and exclusionary processes. It may thus be helpful to view productive nostalgia not as a discrete phenomenon in itself, but as a term that draws attention to these productive consequences. Such an approach recognises that nostalgia can be useful for individuals or wider political projects, but does not necessarily imply that the emotion and its related practices have universal benefits or wholly positive implications. 


\section{Notes}

1. For a more comprehensive overview of the development of local history, see Richardson (2000).

2. Martham Stories is available to view at:

http://www.mediaprojectseast.co.uk/martham/index.html.

\section{Acknowledgements}

This paper was made possible by funding from the Plymouth University Doctoral Training Centre and by the support of the LEEP institute at University of Exeter. I would also like to thank all the Martham residents who participated in the research and two anonymous referees for their constructive comments on an earlier version of the paper.

\section{References}

Anderson, J. (2004) Talking whilst walking: A geographical archaeology of knowledge, Area 36: 254-61.

Ashworth, G. J. and Graham, B. J. (2005) Senses of place, senses of time and heritage, in Ashworth, G. J. and Graham, B. J. (eds.) Senses of Place: Senses of Time, Aldershot: Ashgate, pp. 3-14.

Atkinson, D. (2007) Kitsch geographies and the everyday spaces of social memory, Environment and Planning A 39: 521-40.

Australian Government. (2014) Indigenous Heritage Programme. https://www.environment.gov.au/heritage/grants-funding/indigenous-heritage-programme.

Beckett, J. (2011) Local history in its comparative international context, The Local Historian 41: 90 - 104.

Beckett, J. V. (2007) Writing local history. Manchester: Manchester University Press.

Bell, M. (1994) Childerley: Nature and morality in a country village. Chicago: University of Chicago Press.

Blunt, A. (2003) Collective memory and productive nostalgia: Anglo-Indian homemaking at McCluskieganj, Environment and Planning D: Society and Space 21: 717-38.

Bonnett, A. (2010) Left in the Past: Radicalism and the Politics of Nostalgia. Bloomsbury Academic.

Bonnett, A. (2015) The Geography of Nostalgia: Global and Local Perspectives on Modernity and Loss. Abingdon: Taylor \& Francis.

Bonnett, A. and Alexander, C. (2013) Mobile nostalgias: connecting visions of the urban past, present and future amongst ex-residents, Transactions of the Institute of British Geographers 38: 391-402.

Boym, S. (2001) The Future of Nostalgia. New York, NY: Basic Books.

Bunce, M. (2003) Reproducing rural idylls, in Cloke, P. (ed.) Country Visions, Harlow: Pearson / Prentice-Hall, pp. 14 - 30.

Cloke, P., Cook, I., Crang, P., Goodwin, M., Painter, J. and Philo, C. (2004) Practising human geography. London: SAGE.

Crouch, D. and Matless, D. (1996) Refiguring geography: Parish maps of Common Ground, Transactions of the Institute of British Geographers 21: 236-55.

Cubitt, G. (2007) History and Memory. Manchester: Manchester University Press. 
Day, G. (1998) A community of communities? Similarity and difference in Welsh rural community studies, Economic and Social Review 29: 233-57.

De Jong, F. and Rowlands, M. J. (2007) Reclaiming heritage: alternative imaginaries of memory in West Africa. California: Left Coast Press.

de Wit, C. W. (2012) Interviewing for sense of place, Journal of Cultural Geography 30: 120-44.

DeSilvey, C. (2012) Making sense of transience: An anticipatory history, Cultural Geographies 19: 31-54.

DeSilvey, C., Naylor, S. and Sackett, C. (2011) Anticipatory History. Axminster: Uniform Books.

Duncan, J. S. and Duncan, N. G. (2004) Landscapes of Privilege: Aesthetics and affluence in an American suburb. London: Routledge.

Harrison, D. (2004) Introduction: Contested Narratives in the Domain of World Heritage, Current Issues in Tourism 7: 281-90.

Harvey, D. (1989) The Condition of Postmodernity: An Enquiry into the Origins of Cultural Change. Oxford: Basil Blackwell.

Harvey, D. C. (2001) Heritage pasts and heritage presents: Temporality, meaning and the scope of heritage studies, International Journal of Heritage Studies 7: 319-38.

Harvey, D. C. (2014) Heritage and scale: settings, boundaries and relations, International Journal of Heritage Studies 21: 577-93.

Hoelscher, S. (2007) Heritage, in MacDonald, S. (ed.) A Companion to Museum Studies, Oxford: Blackwell, pp. 198-218.

Hoskins, W. G. (1955) The Making of the English Landscape. Hodder \& Stoughton.

Huigen, P. P. P. and Meijering, L. (2005) Making places: a story of De Venen, in Ashworth, G. J. and Graham, B. J. (eds.) Senses of place: Senses of time, Aldershot: Ashgate, pp. 19-30. Jackson, A. (2008) Local and Regional History as Heritage: The Heritage Process and Conceptualising the Purpose and Practice of Local Historians, International Journal of Heritage Studies 14: 362-79.

Ladino, J. (2010) "Local Yearnings": Re-placing nostalgia in Don DeLillo's Underworld, Journal of Ecocrticism 2: 1-18.

Legg, S. (2004) Memory and nostalgia, Cultural Geographies 11: 99-107.

Legg, S. (2005) Sites of counter-memory: The refusal to forget and the nationalist struggle in colonial Delhi, Historical Geography 33: 180-201.

Lewicka, M. (2011) On the varieties of people's relationships with places: Hummon's typology revisited, Environment and Behavior 43: 676-709.

Lewicka, M. (2013) In search of roots: memory as enabler of place attachment, in Manzo, L.

C. and Devine-Wright, P. (eds.) Place Attachment: Advances in theory, methods and applications, Abingdon: Routledge, pp. 49-60.

Local History Magazine. (2010) Local History Online. http://www.localhistory.co.uk/Groups/ (accessed 09/07/2015.

Lowenthal, D. (1985) The Past is a Foreign Country. Cambridge: Cambridge University Press.

Lowenthal, D. (1998) The Heritage Crusade and the Spoils of History. Cambridge: Cambridge University Press.

Mackenzie, A. F. D. (2004) Re-Imagining the land, North Sutherland, Scotland, Journal of Rural Studies 20: 273-87.

Mackenzie, A. F. D. (2006) A working land: Crofting communities, place and the politics of the possible in post-Land Reform Scotland Transactions of the Institute of British Geographers 31: 383-98. 
Mah, A. (2012) Industrial Ruination, Community and Place: Landscapes and legacies of urban decline. Toronto: University of Toronto Press.

Martham Local History Group. (2012) Wings over Norfolk. http://marthamlocalhistorygroup.sharepoint.com/Pages/WingsOverNorfolk.aspx $\quad$ (accessed 15/07/15.

Martham Local History Group. (2015) About Us. http://marthamlocalhistorygroup.sharepoint.com/Pages/aboutus.aspx (accessed 16/07/15.

Martham Parish Council. (2010) Village Green and Open Spaces. http://www.martham.gov.uk/parishcouncil/vgreens.htm (accessed 02/06/14.

Massey, D. (1995) Places and their pasts, History Workshop Journal 39: 182-92.

Massey, D. (2006) Landscape as a provocation: Reflections on moving mountains, Journal of Material Culture 11: 33-48.

Massey, D. B. (1994) Space, Place and Gender. Cambridge: Polity Press.

Matless, D. (1998) Landscape and Englishness. London: Reaktion.

Matless, D. and Cameron, L. (2007) Geographies of Local Life: Marietta Pallis and Friends, Long Gores, Hickling, Norfolk, Environment and Planning D: Society and Space 25: 75-103.

Media Projects East. (2013) Martham Stories. http://www.mediaprojectseast.co.uk/martham/ (accessed 08/09/14.

Murdoch, J. and Marsden, T. (1994) Reconstituting Rurality: Class, community and power in the development process. London: UCL Press.

Nash, C. (2005) Local histories in Northern Ireland, History Workshop Journal 60: 45-68.

Nymoen Rørtveit, H. and Setten, G. (2015) Modernity, Heritage and Landscape: The Housing Estate as Heritage, Landscape Research: 1-16.

Phillips, M. (1993) Rural gentrification and the processes of class colonisation, Journal of Rural Studies 9: 123-40.

Phillips, M. (2002) The production, symbolization and socialization of gentrification: impressions from two Berkshire villages, Transactions of the Institute of British Geographers 27: 282-308.

Pred, A. (1984) Place as historically contingent process: Structuration and the timegeography of becoming places, Annals of the Association of American Geographers 74: 27997.

Relph, E. C. (1976) Place and Placelessness. London: Pion Limited.

Richardson, R. C. (2000) The Changing Face of English Local History. Ashgate.

Said, E. W. (2000) Invention, memory, and place, Critical Inquiry 26: 175-92.

Seamon, D. (1980) Body-subject, time-space routines, and place-ballets, in Buttimer, A. and Seamon, D. (eds.) The Human Experience of Space and Place, London: Croom Helm, pp. 148-65.

Sheeran, G. and Sheeran, Y. (1998) Discourses in local history, Rethinking History 2: 65-85.

Short, J. R. (1991) Imagined Country: Environment, culture, and society. London: Routledge.

Smith, L., Shackel, P. and Campbell, G. (2012) Heritage, Labour and the Working Classes. Abingdon: Routledge.

Sturzaker, J. (2010) The exercise of power to limit the development of new housing in the English countryside, Environment and Planning A 42: 1001-16.

Tewdwr-Jones, M. (1998) Rural government and community participation: The planning role of community councils, Journal of Rural Studies 14: 51-62.

Tomaney, J. (2013) Parochialism - a defence, Progress in Human Geography 37: 658-72.

Tomaney, J. (2014) Region and place 2: Belonging, Progress in Human Geography.

Tourism RESET. (2016) Research \& themes. http://tourismreset.com/wordpress/?page id=10 (accessed 02/02/2016. 
Tuan, Y.-f. (1977) Space and Place: The perspective of experience. London: Edward Arnold. Waterton, E. and Smith, L. (2010) The recognition and misrecognition of community heritage, International Journal of Heritage Studies 16: 4-15.

Watson, S. and Wells, K. (2005) Spaces of nostalgia: the hollowing out of a London market, Social \& Cultural Geography 6: 17-30.

Wheeler, R. (2014) Mining memories in a rural community: Landscape, temporality and place identity, Journal of Rural Studies 36: 22-32.

Woods, M. (2005) Contesting Rurality: Politics in the British countryside. Aldershot: Ashgate.

Woods, M. (2011) Rural. London: Routledge.

Yarwood, R. (2002) Parish councils, partnership and governance: The development of 'exceptions' housing in the Malvern Hills District, England, Journal of Rural Studies 18: 275-91. 